\title{
Nauka umiejętności przekształcania rzeczywistości przestrzeni miejskich przez studentów. Przykład Oświęcimia
}

\author{
Learning the Skill of Transforming the Reality of \\ Urban Spaces by Students. Example of Oświęcim
}

\section{Streszczenie}

Od roku 2015 na Wydziale Architektury Politechniki Krakowskiej przygotowywane są przez studentów oraz dyplomantów opracowania projektowe, projekty koncepcyjne, które stanowią propozycję projektową we wskazanych przez przedstawicieli miast lokalizacjach. Studenci opracowują również oferty inwestorskie, które mogą stanowić punkt wyjścia do omówieni rentowności inwestycji. W dobie konkurencyjności związanej z rynkiem pracy studenci, dzięki współpracy Uczelnia - Samorząd - Biznes, otrzymują określoną wiedzę związaną z procesem projektowym i inwestycyjnym, poznają miasta, ich specyfikę. Współpraca z młodymi ludźmi otwiera nowe możliwości, gdyż pomysły i aktywności gospodarcze mogą być czasami dostrzeżone tylko przez młode pokolenie. Ich spojrzenie i pomysły również przyczyniają się do ożywienia przestrzeni miejskich. Tego typu działania są korzystne dla miast.

Słowa kluczowe: współpraca uczelnia - samorząd - biznes, atrakcyjność, konkurencyjność miast

Abstract

Since 2015 students of different years and diploma candidates studying at the Faculty of Architecture, Cracow University of Technology, develop design studies and conceptual designs, which constitute design proposals for locations indicated by representatives of town councils. Students also prepare 'investor's offers', which could constitute a starting point for studies devoted to feasibility of particular investments. In the era of job market competition, thanks to the collaboration along the line University - Local Government - Business, students acquire specific knowledge relating to the designing and investment process; they get to know different towns and cities, their specificity. Cooperation with young people opens up new opportunities, because sometimes some concepts and business activities can be perceived only by the young generation. Their approach and ideas contribute to the revival of urban spaces, as well.

Keywords: collaboration University - Local Government - Business, attractiveness, competitiveness of cities 


\section{WSTĘP}

Oferta związana z opracowaniami studenckich koncepcji projektowych skierowana jest do przedstawicieli miast i gmin, mieszkańców oraz otoczenia gospodarczego. Kładzie nacisk na porządek i ład przestrzenny w miastach i gminach, na aktywność społeczną, a w szczególności niesie myśl gospodarczą. Dzięki opracowaniom studenckim możliwe jest tworzenie i przeanalizowanie modeli propozycji projektowych. Student natomiast ma możliwość uczenia i poznawania sprawdzonego w praktyce. Droga poznania to droga nawracania, zawracania, ustawicznego poszukiwania, kreacji i doskonalenia się.

Wiedza studenta to nie tylko obeznanie w podręcznikach, planach i różnych materiałach, ale również umiejętność, którą trzeba nabyć w procesie interakcji z rzeczywistością. Umiejętność na wyższym poziomie - mająca podstawy wiedzy naukowej i zmierzająca do jej przekształcania. To nie tylko poznanie sytuacji, ale również tworzenie nowego otoczenia.

To nowe, świeże spojrzenie młodych ludzi, o dużym potencjale kreatywności, chcących zmienić świat, może stanowić ciekawą propozycję dla wielu miast, które borykają się z problemami przestrzennymi, społecznymi, gospodarczymi.

\section{KONKURENCYJNOŚĆ I ATRAKCYJNOŚĆ MIAST}

Transformacja społeczno-gospodarcza, która miała miejsce w Polsce w 1989 r., związana z porzuceniem systemu komunistycznego, spowodowała powrót gospodarki rynkowej. Jej konsekwencją były widoczne zmiany zachodzące w przestrzeni miasta.

Samorządy terytorialne reprezentować zaczęły interesy lokalnych społeczności. Znacznie wzrosła liczba osób, które mogły wpływać na przestrzeń miejską. Dynamicznej zmianie ulegały krajobraz i architektura, wzrastała intensywność użytkowania ziemi, ulegały zmianie funkcje wielu obszarów miasta ${ }^{1}$.

Miasta zaczęły konkurować pomiędzy sobą, stawały się coraz bardziej atrakcyjne gospodarczo. Te cechy przyciągały nowych mieszkańców, mając istotny wpływ na ich proces urbanizacji.

Cechy miasteczek, ich atrakcyjność i konkurencyjność, obecnie mogą mieć wpływ na proces racjonalnego wykorzystania terenów miejskich. Wszelkie poczynania nakierowane są na poprawę środowiska miejskiego, poprawę jakości życia i mieszkania oraz jakości przestrzeni miejskich. W dużej mierze działania w tkance miejskiej polegają na przystosowaniu istniejących zasobów do zmieniających się potrzeb użytkowników.

„Pustostany” - lokale użytkowe i mieszkalne, budynki, przez wiele lat zaniedbywane, widoczne w centrach miast i miasteczek - zaczynają ulegać postępującej degradacji, dekapitalizacji, negatywnie wpływając na wizerunek miejsca.

Degradacja przestrzeni miejskiej, powiązana z niską jakością życia i zamieszkania, spowodowała brak atrakcyjności, żywotności, na korzyść wzrostu aktywności przestrzeni komercyjnych. 
A przecież przestrzeń pomiędzy miejscem zamieszkania a miejscem pracy ma szczególny wpływ na jakość życia człowieka - obok aspektu przestrzennego jest bowiem aspekt społeczny. Zjawisko wyludniania się kamienic z powodu złej jakości życia i zamieszkania doprowadziło do sytuacji, w której stopniowo miasta stały się pozbawione różnorodności i bogactwa życia społecznego.

Niska jakość przestrzeni publicznych, wywołuje wiele negatywnych emocji powiązanych z odczuciem zagrożenia bezpieczeństwa użytkowników danej przestrzeni. Przyczynia się do niechęci w niej przebywania, zamieszkania, użytkowania danej przestrzeni. Zaniedbane, zdegradowane przestrzenie stopniowo stają się niczyje.

Zjawiskiem, które powinno niepokoić, jest przyrost naturalny. Miasteczka stają się coraz bardziej opuszczone przez młodzież, która nie widzi już perspektywy rozwoju. Pozostają ludzie starsi, którzy z powodów ekonomicznych nie mają możliwości zmiany swojego miejsca zamieszkania.

Bezrobocie, niskie dochody, zmiany struktury społecznej jak również przyzwyczajenia przedkładają się na obraz miasta, jego atrakcyjność jako miejsca do zamieszkania. Ta słaba kondycja materialna mieszkańców, brak napływającego kapitału zewnętrznego, w znacznej mierze ograniczają atrakcyjność w formie lokaty kapitału.

Zaginęły miejsca, które tętniły różnorodnym życiem społecznym. To zróżnicowanie dotyczy ludzi: pod względem wieku, orientacji seksualnych i wyglądu, stanowiących mieszankę kultur, narodowości, również ludzi kreatywnych, którzy posiadają " kapitał kreatywny”.

Powiązanie różnorodnych funkcji w przestrzeni w celu realizacji potrzeb i aspiracji człowieka, uczestnika przestrzeni, prowadzi do bezpiecznych, tętniących życiem miejsc. Podnoszenie ich atrakcyjności i jakości następuje poprzez promocję kultury, sztuki, rozrywki, poprawę ich dostępności i stanu komunikacji miejskiej: pieszej, rowerowej, szynowej, autobusowej.

Ludzie zamieszkujący miasta stanowią „kapitał społeczny”, dzięki któremu możliwe jest jego funkcjonowanie. Inwestowanie w infrastrukturę społeczną, jej poziom rozwoju, może mieć istotny wpływ na atrakcyjność i konkurencyjność miasteczek, jako miejsc, które się rozwijają. Umiejętność współpracy, organizowanie się w celu realizacji wspólnych interesów, jak również tworzenie i spotkania w grupach, klubach towarzyskich - to wszystko tworzy kapitał społeczny.

Badania wykazują, że ludzie, którzy żyją w społeczeństwie o wysokim poziomie kapitału społecznego, wyróżnia niższy wskaźnik przestępczości oraz wyższy poziom życia. Mieszkańcy miast stają się bardziej przywiązani do miejsc swojego zamieszkania i chcą tam pozostać i inwestować.

Większość firm o kluczowym znaczeniu dla rozwoju miast, działa tam, gdzie występuje skupisko zdolnych, utalentowanych młodych ludzi. Miasta rozwijają się dzięki tym, którzy chcą w nich mieszkać i zakładać przedsiębiorstwa.

Dla ludzi kreatywnych liczą się nie tylko względy ekonomiczne, ale również styl życia. Poszukują miejsc otwartych na różnorodność. Nieistotne, nieatrakcyjne są dla nich miejsca 
takie jak centra handlowe. Umiejętność przyciągnięcia ich do siebie z różnych środowisk, utalentowanych, pełnych życia, energii i pomysłów, powinno stać się naczelnym zadaniem chcących się rozwijać miast, chcących być atrakcyjnymi i kreatywnymi.

\section{WSPÓŁPRACA URZĄD MIASTA OŚWIĘCIM - WYDZIAŁ ARCHITEKTURY PK, INSTYTUT PROJEKTOWANIA URBANISTYCZNEGO}

Na Wydziale Architektury Politechniki Krakowskiej dnia 15.10.2014 r. zostało podpisane Porozumienie między Dziekanem Wydziału Architektury prof. drem hab. inż. arch. ackiem. Gyurkovichem a Prezydentem Miasta Oświęcim Januszem Chwierutem, będące deklaracją współpracy. Stworzone zostały projekty partnerskie na rzecz przygotowania studenckich koncepcji zagospodarowania terenów w Oświęcimiu. Dotyczyły one lokalizacji ul. Leszczyńskiej, ul. Stolarskiej, które były tematami dyplomowymi. W ramach zajęć z przedmiotu Projektowanie architektoniczno-urbanistyczne jednorodzinnych zespołów mieszkaniowych (prowadzący: dr hab. inż. arch. Krystyna Paprzyca, mgr inż. arch. Julian Franta rok akademicki 2014/15) studenci II roku przygotowywali opracowania projektowe związane z lokalizacjami: ul. Strzelecka, ul. Dąbrowskiego, ul. Nideckiego (il. 1-4).

W pierwszym etapie grupa studentów pojechała do Oświęcimia, spotkała się z przedstawicielami Urzędu Miasta i obejrzała wskazane przez miasto lokalizacje. Szczególna wartość prowadzonych tematów związana jest z praktyką projektową i inwestorską. Umożliwia studentom bezpośredni kontakt nie tylko z przedstawicielami miasta, środowiskiem społeczno-gospodarczym, ale także zaznajomienie się ze specyfiką miasta. Studenci uczestniczyli w spotkaniu z przedstawicielami urzędów podczas przeglądów: Prezydentem Miasta Oświęcim Januszem Chwierutem oraz Naczelnik Wydziału Inwestycji Magdaleną Stapurewicz (il. 1, 2). Dzięki takim spotkaniom studenci otrzymali dodatkowe wskazówki związane z opracowaniami.

Miasto Oświęcim przyznało nagrody. W wyborze najlepszych opracowań uczestniczyli przedstawiciele Urzędu Miasta Oświęcim, biur projektowych, przedstawiciele środowiska akademickiego (il. 3, 4). Wydział Architektury zorganizował również na terenie Politechniki Krakowskiej w Galerii Gil i Galerii Kotłownia wystawę pt. Uczelnia - samorzq̨d - biznes, podczas której prezentowane były najciekawsze opracowania, studenckie kreacje urbanistyczno-architektoniczne związane z Miastem Oświęcim. Wystawa jest cykliczna, zapraszani są na nią przedstawiciele miast i środowiska społeczno-gospodarczego.

Również w miastach partnerskich organizowane są wystawy prezentujące opracowania studentów Wydziału Architektury Politechniki Krakowskiej. Miasto Oświęcim zorganizowało wystawę w Bibliotece Publicznej - październik 2015. Opracowania studenckie prezentowane również były na profilach internetowych. Zorganizowano konkurs wśród mieszkańców na najciekawszą pracę. Stanowi to rodzaj konfrontacji studenckich idei i pomysłów projektów architektoniczno-urbanistycznych z wizjami i potrzebami mieszkańców (il. 10-16). 


\section{PODSUMOWANIE}

Projekty partnerskie Wydziału Architektury z samorządem i otoczeniem gospodarczym mają duże znaczenie. Polskie firmy przy zatrudnianiu absolwentów najczęściej narzekają na bark ich doświadczenia, słabą komunikatywność, brak umiejętności pracy zespołowej. Pracownie architektoniczne zatrudniające młodych architektów oczekują ludzi kreatywnych, z pomysłami, z wyobraźnią, niebojących się wyzwań, posiadających umiejętności pracy w terenie. W systemie edukacji zdecydowanie brakuje praktycznej strony zawodu.

Kontakt z przedstawicielami urzędu, biur projektowych, biznesem, z mieszkańcami miast daje studentom możliwość pogłębiania własnych umiejętności: uczy umiejętności komunikowania się z ludźmi, przekonywania ich do swoich racji, inspirowania, współpracy w zespole, komunikatywności, elastyczności. Pomaga rozwijać kompetencje, które w obecnych czasach są inwestycją w samego siebie. Dzięki niej stajemy się dla pracodawców bardziej atrakcyjni.

Współpraca Uczelnia - Samorząd umożliwia Wydziałowi Architektury start w Funduszach Europejskich w zakresie podnoszenia kwalifikacji zawodowych dla architektów. Współpraca umożliwia również uczestnictwo środowiskom samorządowym i biznesowym w Konferencjach, seminariach, studiach podyplomowych, przyczyniając się do integracji miedzy ludźmi nauki, samorządu.

Celem jest spotkanie ludzi kreatywnych z różnych środowisk: władz samorządowych, biznesu, przedstawicieli środowiska naukowego, studentów. Chcących zmienić świat. Ludzi, którzy są odpowiedzialni z środowisko, w którym żyjemy, które funkcjonuje na zasadzie naczyń połączonych. Stąd tak istotne znaczenie ma współpraca i wymiana poglądów nt. Uczelnia - Samorząd - Biznes. 

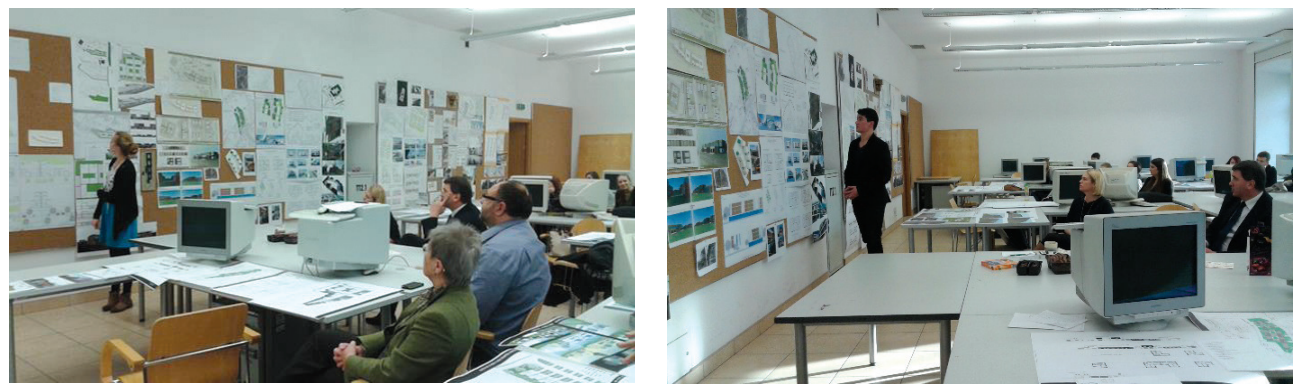

II. 1, 2. II rok. Przegląd opracowań studenckich. Spotkanie na Wydziale Architektury PK: Prezydent Miasta Oświęcim Janusz Chwierut, Naczelnik Wydziału Inwestycji Magdalena Stapurewicz, Dziekan WA prof. dr hab. inż. arch. Jacek Gyurkovich, prof. dr hab. inż. arch. Grażyna Schneider-Skalska, dr hab. inż. arch. Krystyna Paprzyca, mgr inż. arch. Julian Franta, dr inż. arch. Tomasz Gaczoł, studenci II roku WA PK (fot. K. Paprzyca)
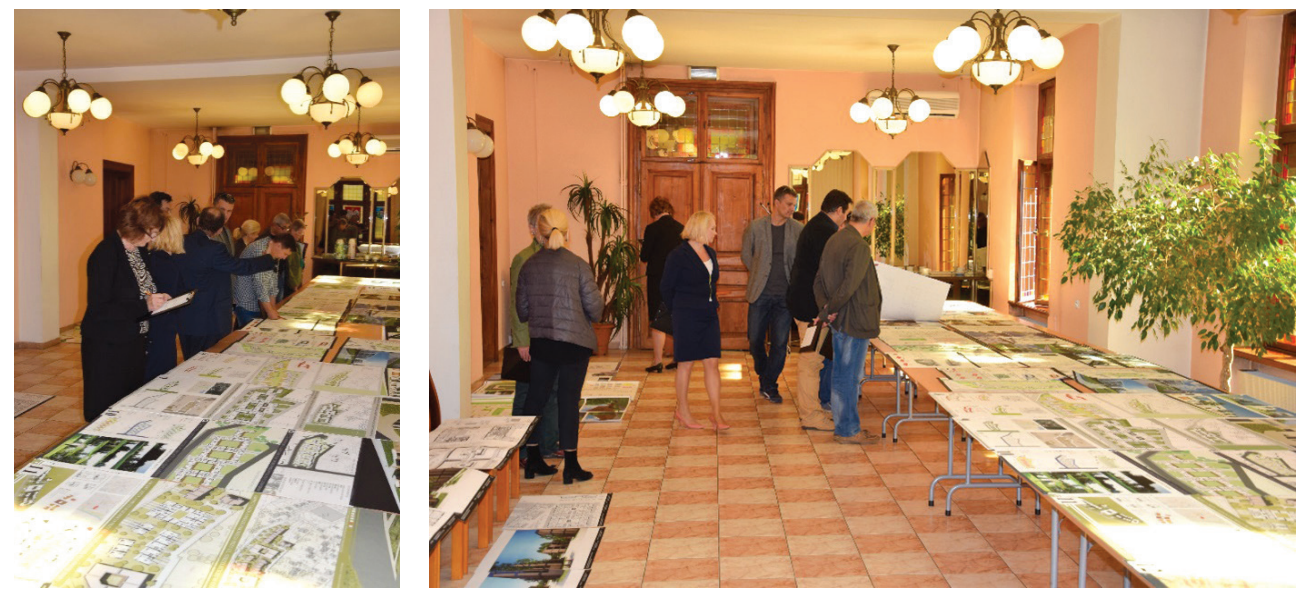

II. 3, 4. Wybór najlepszych opracowań studenckich. Urząd Miasta Oświęcim, Przedstawiciele Urzędu Miasta: Zastępca Prezydenta Miasta Oświęcim Andrzej Bojarski, Naczelnik Wydziału Inwestycji Magdalena Stapurewicz, Inspektor Wydziału Inwestycji Paweł Kubica, Naczelnik Wydziału Architektury Jadwiga Pachołek, Biuro Projektowe Susuł i Strama, prof. dr hab. inż. arch. Grażyna Schneider Skalska, dr hab. inż. arch. Krystyna Paprzyca, mgr inż. arch. Julian Franta z Wydziału Architektury PK (fot. K. Paprzyca) 

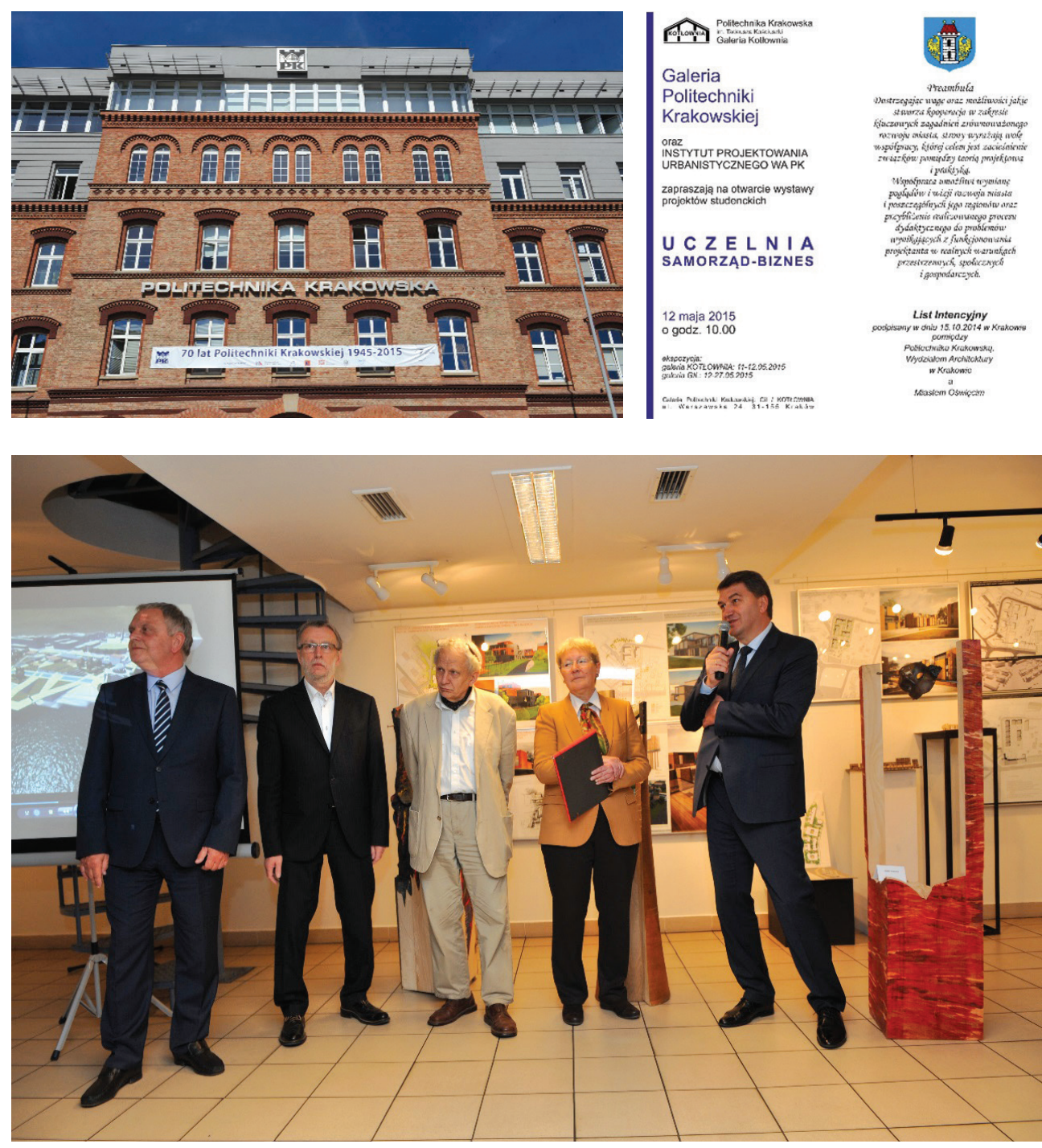

II. 5-7. Otwarcie wystawy pt. Uczelnia - Samorzqd - Biznes (z okazji 70-lecia PK). Rektor dr hab. inż. arch. Andrzej Białkiewicz, prof. PK, Dziekan WA prof. dr hab. inż. arch. Jacek Gyurkovich, prof. art. Stefan Dousa, prof. dr hab. inż. arch. G. Schneider-Skalska, Prezydent Miasta Oświęcim Janusz Chwierut (fot. K. Paprzyca) 

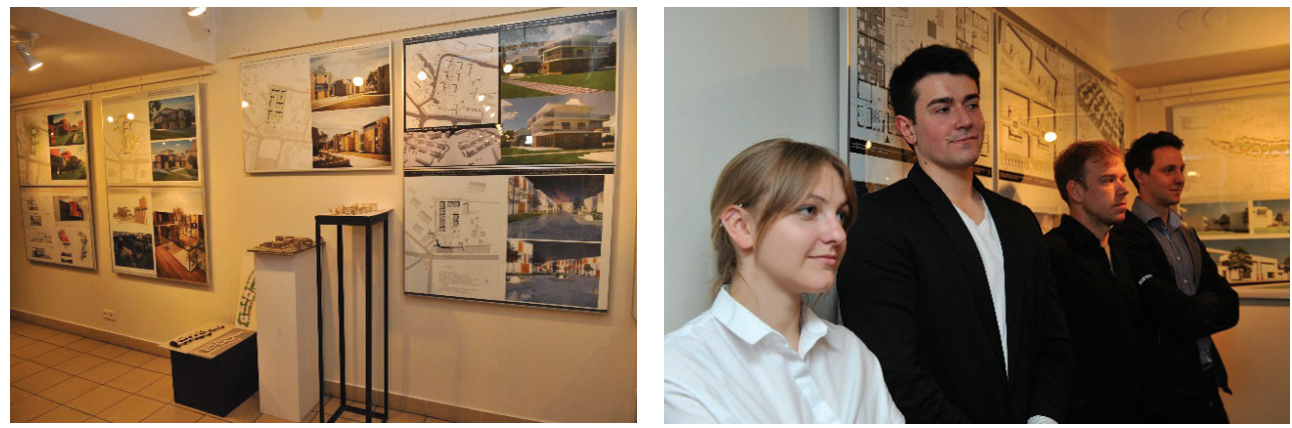

II. 8, 9. Wystawa Galeria Kotłownia, studenci II roku WA PK (fot. K. Paprzyca)

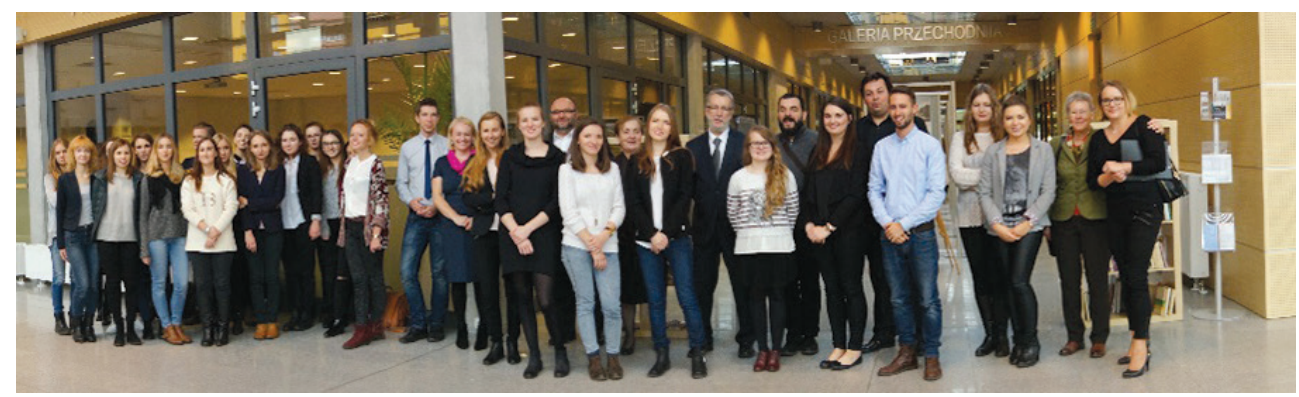

II. 10. Wystawa prac studenckich. Biblioteka w Oświęcimiu. Zdjęcie zespołowe: studenci II roku, dyplomanci WA PK 

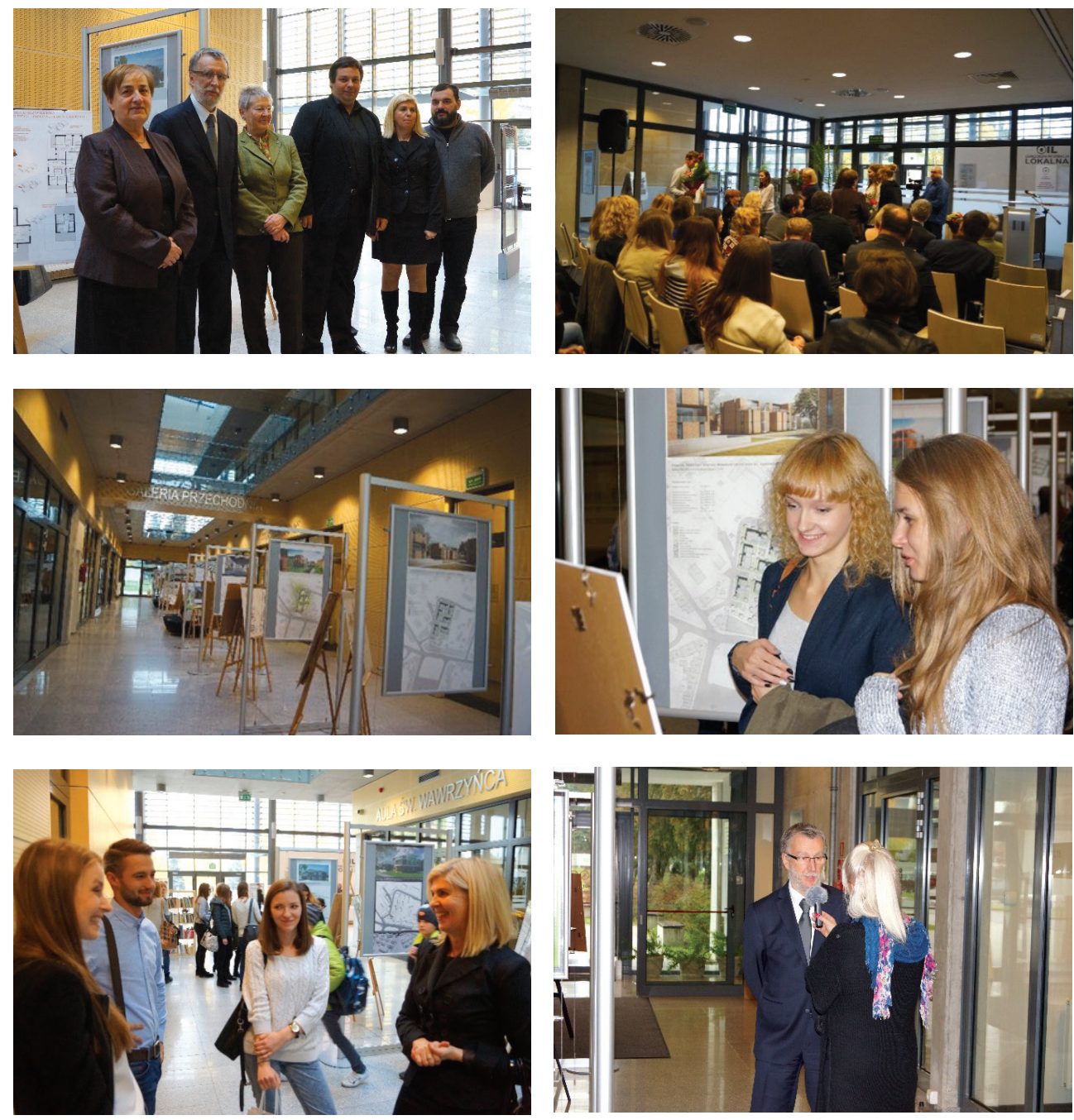

II. 10-15. Wystawa prac studenckich, październik 2015. Zastępca Prezydenta Miasta Oświęcim Maria Pędrak, Dziekan WA prof. dr hab. inż. arch. Jacek Gyurkovich, prof. dr hab. inż. arch. Grażyna SchneiderSkalska, dr hab. inż. arch. Mateusz Gyurkovich, dr hab. inż. arch. Krystyna Paprzyca, mgr inż. arch. Julian Franta, mgr Małgorzata Rekuć, Naczelnik Wydziału Inwestycji Magdalena Stapurewicz, Inspektor Wydziału Inwestycji Paweł Kubica, studenci II roku, dyplomaci WA PK (fot. K. Paprzyca) 


\section{BIBLIOGRAFIA}

Alkinous, Wykład Nauk Platona, źródło Myśli Filozoficznej, Wyd. WAM, Kraków 2008.

Auge M., Nie-miejsca, wprowadzenie do antropologii hipernowoczesności, Wydawnictwo Naukowe PWN, Warszawa 2012.

Baudrillard J., Społeczeństwo konsumpcyjne, jego mity i struktury, Wyd. Sic!, Warszawa 2006.

Cichy-Pazder E., Humanistyczne podstawy kompozycji miast, Politechnika Krakowska, Kraków 1998.

Gadamer H.G., Aktualność piękna: sztuka jako gra, symbol i święto, przeł. Krystyna Krzemieniowa, Warszawa 1993.

Gehl J., Życie między budynkami. Użytkowanie przestrzeni publicznych, Wyd. RAM, Kraków 2009.

Gyurkovich J., Znaczenie form charakterystycznych dla kształtowania i percepcji przestrzeni, Monografia Nr 258, Politechnika Krakowska, Seria Architektura, Kraków 1999.

Hegel G.W., Wykłady z filozofii dziejów, tom. II, ks. 2, Świat grecki, Warszawa 1958.

Kosiński W., Miasto i piękno miasta, Wyd. Politechniki Krakowskiej, Kraków 2011.

Paprzyca K., Harmonizowanie rozwoju urbanistycznego terenów miejskich - wybrane zagadnienia, Monografia 417, Kraków, Wyd. Politechniki Krakowskiej, Kraków 2012.

Paszkowski Z., Miasto idealne w perspektywie europejskiej i jego zwiq̨zki z urbanistykq współczesnq, Wyd. Universitas, Kraków 2011.

Riesman D., Samotny tłum, Wyd. vis-a-vis/ Etiuda, Kraków 2011.

Ritzer G., Magiczny świat konsumpcji, Warszawskie Wydawnictwo Literackie MUZA, Warszawa 2012.

Sennett R., Upadek człowieka publicznego, Warszawskie Wydawnictwo Literackie MUZA, Warszawa 2009.

Schneider-Skalska G., Kształtowanie zdrowego środowiska mieszkaniowego. Wybrane zagadnienia, Politechnika Krakowska, Monografia 307, Kraków 2004.

Tandera P., Od filozofii światła do sztuki światła, Monografia, Uniwersytet Jagielloński, Tom III, Kraków 2014.

Wallis A., Miasto i przestrzeń, Warszawa 1977. 